\title{
The Qualitative Approach Interview in Administration: A Guide for Researchers
}

\author{
A Entrevista de Abordagem Qualitativa em Administração: Um Guia para \\ Pesquisadores
}

\author{
Cibele Cheron ${ }^{10}$ \\ Julice Salvagni*2ø \\ Renato Koch Colomby ${ }^{3}$
}

\section{ABSTRACT}

Context: this paper explores different ways of using qualitative approach interviews, based on the assumption that the interview is not exclusively subjective or objective, but intersubjective, allowing participants to discuss and express their interpretations about the social world. Objective: the aim is to guide the use of the interview, step by step, in research in administration and related areas, offering a simplified guide to assist beginning and experienced researchers. Method: due to its objective, this tutorial article is descriptive and explanatory, interdisciplinary and supported by bibliographic sources. Results: theoretical considerations about the interview are made, conceptualizing essential aspects related to its structuring, development and evaluation. Also listed are the factors resulting from the intersubjectivity inherent in the act of researching, such as the potential types of interview, the dimensions of the preparation, the different possibilities of asking, the questions about the conduct of the meeting, the dimensions related to the analytical work, among others. Conclusion: as an outcome, it is suggested that the interviewer observe the asymmetry of the relationship with the interviewee, the inevitable presence of biases and distortions, and the rigor in planning the investigation.

Keywords: research methods for administration; qualitative approach; interview; step-by-step application.

\footnotetext{
* Corresponding Author.

1. Pontifícia Universidade Católica do Rio Grande do Sul, Escola de Humanidades, Programa de PósGraduação em Educação, Porto Alegre, RS, Brazil.

2. Universidade Federal do Rio Grande do Sul, Escola de Administração, Porto Alegre, RS, Brazil.

3. Instituto Federal de Educação Ciência e Tecnologia do Paraná, Colegiado de Administração, Palmas, PR, Brazil.

Cite as: Cheron, C., Salvagni, J., \& Colomby, R. K. (2022). The qualitative approach interview in Administration: A guide for researchers. Revista de Administração Contemporânea, 26(4), e210011.
} https://doi.org/10.1590/1982-7849rac2022210011.en

Published as Early Access: December 16, 2021

Assigned to this issue: January 06, 2022.

\# of invited reviewers until the decision:

\begin{tabular}{|c|c|c|c|c|c|c|c|c|c|}
\hline & 1 & 2 & 3 & 4 & 5 & 6 & 7 & 8 & 9 \\
\hline $1^{\text {st }}$ round & $\frac{9}{2}$ & (x) & & & & & & & \\
\hline $2^{\text {nd }}$ round & (x) & (x) & 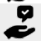 & (x) & p) & & & & \\
\hline $3^{\text {rd }}$ round & 9 & (x) & & & & & & & \\
\hline
\end{tabular}

Contexto: este artigo explora diferentes formas de utilização de entrevistas com abordagem qualitativa, partindo da premissa de que a entrevista não é exclusivamente subjetiva ou objetiva, mas intersubjetiva, permitindo aos participantes discutir e expressar suas interpretações sobre o mundo social. Objetivo: busca-se orientar a aplicação da entrevista, passo a passo, em pesquisas em administração e áreas afins, oferecendo um guia simplificado para auxiliar pesquisadores iniciantes e experientes. Método: em razão do seu objetivo, este artigo-tutorial é descritivo e explicativo, interdisciplinar e subsidiado por fontes bibliográficas. Resultados: são feitas consideraçóes teóricas sobre a entrevista, conceituando aspectos essenciais, relacionados à estruturação, desenvolvimento e avaliação. Também são elencados fatores decorrentes da intersubjetividade inerente ao ato de pesquisar, tais como os tipos potenciais de entrevista, as dimensões da preparação, as diferentes possibilidades de perguntar, as questóes sobre a conduçáo do encontro, as dimensóes inerentes ao trabalho analítico, entre outros. Conclusão: como desfecho, sugere-se que o entrevistador observe a assimetria da relaçáo com o entrevistado, a presença inevitável de vieses e distorçóes e o rigor no planejamento da investigação.

Palavras-chave: métodos de pesquisa em administração; abordagem qualitativa; entrevista; aplicação passo a passo.

EL Code: B490, Y200, Y800

Editors-in-chief: Wesley Mendes-da-Silva (Fundação Getulio Vargas, EAESP, Brazil) (10) Marcelo de Souza Bispo (Universidade Federal da Paraíba, PPGA, Brazil) (c) Guest Editors: Evelyn Lanka (Cranfield School of Management, United Kingdom) (1) Sanjay Lanka (Fundação Getulio Vargas, EAESP, Brazill) Ali Rostron (University of Liverpool, United Kingdom) (c) Pallavi Singh (Sheffield Hallam University, United Kingdom) Reviewers: Three reviewers chose not to disclose their identities. Peer Review Report: The disclosure of the Peer Review Report was not authorized by its reviewers. 


\section{INTRODUCTION}

Although the research tradition in the administration area has favored studies with a quantitative approach, the relevance of qualitative research has been evidenced as the focus of interest moves from the search for maximizing efficiency to the human and socio-historical dimension of organizations (Lanka, Lanka, Rostron, \& Singh, 2021). In the same sense, the limitations of the quantitative approach to capture the complexity existing in organizations were recognized, in order to align the field with the epistemic turns driven by the $20^{\text {th }}$ century (Rodrigues, Neves, 8 Anjos, 2016). In this context, this article is part of the proposal to discuss qualitative research in administration, with the objective of structuring a step-by-step guide to researchers, especially those not yet familiarized with the use of interviews according to this approach, as a data production method.

Composed of a varied set of resources, instruments, and techniques, it is recommended to conduct the interview in the context of applied social research, understanding that the participants actively contribute to the achievement of the intended objectives. However, there are "problems involving the researcher's own interaction with the one who studies" (Becker, 1993, p. 27), hence the constant need for analytical exercise of methods.

The interview, in administration as well as in other fields of applied social sciences and humanities, in general, does not have exclusively subjective or objective characteristics, but it is intersubjective, allowing participants - whether they are interviewers or interviewees - to discuss their interpretations of the world and express how they perceive situations according to their singularities. The perspective advocated in this article is that the interview consists of dynamic 'inter-views,' that is, an exchange of views of two or more people on a topic for which they share some interest (Kvale, 1996). Thus, the interview is understood as a dynamic and relational technique.

The interaction between interviewer and interviewee is central to the production of knowledge, in close connection with the circumstances inherent to each of them. The use of the interview marks a reframing effort by those involved in the research process, ceasing to be perceived as mere sources of information. Therefore, the production of knowledge is a construction in which all participants operate and the data, instead of simply being collected, are co-produced.

The interview is a versatile tool for data production, allowing the use of multisensory channels: verbal, nonverbal, speech, and listening. It can be structured, without removing space for spontaneity, and the researcher can conduct the process both to obtain more information on the question investigated and to deepen more complex or important content. It is, therefore, a valuable instrument for the construction of knowledge. However, like all research methods, the interview also has weaknesses and contraindications, which the researcher must be aware of and for which he must prepare himself: potential high financial cost, delay in the data production stage, subjection to bias of the researcher himself, low receptivity or low responsiveness of the interviewees, among other issues that will be addressed throughout this article.

\section{THEORETICAL CONSIDERATIONS ABOUT THE INTERVIEW}

As defined by Kvale (1996), the interview "is a construction site for knowledge. An interview is literally an inter-view, an inter-change of views between two persons conversing about a theme of mutual interest" (Kvale, 1996, p. 14). From this notion, three aspects are highlighted, in Figure 1, to think of the qualitative approach interview as a research method in administration.

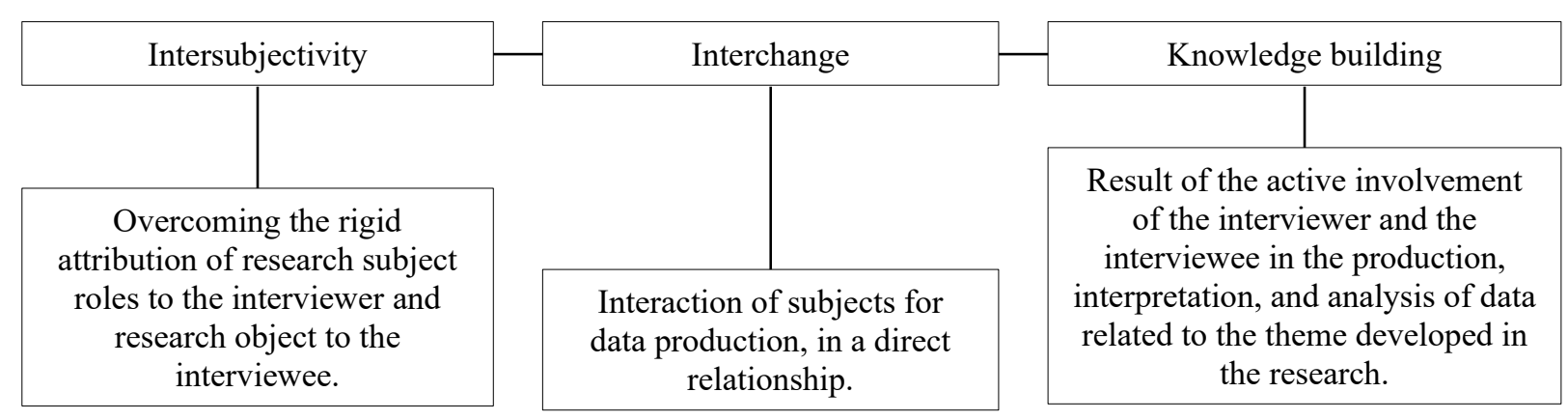

Figure 1. Essential aspects of the qualitative approach interview as a research method in administration.

Source: Author's own elaboration. 
When emphasizing intersubjectivity as one of its essential aspects, a perspective is adopted according to which the interview inevitably presents biases, due to the active participation of the interviewer and the interviewee, subjects of the production, interpretation, and analysis of the data. Intersubjectivity leads the researcher to take into account the varied range of motivations and non-rational factors that govern human behavior, such as emotions, unconscious needs, and interpersonal influences, present in many circumstances of conviviality. However, although the scientific construction presupposes a distortion of 'reality,' given the researcher's interference, this does not mean that there must be a distortion of the 'truth' (Santos, 1987).
To deal with these factors, what is required are not mechanisms for eliminating or controlling the biases inherent in the relationships between the subjects, but the foundation of a theory of everyday life that considers intersubjectivity. The subjects - interviewer and interviewee - weave the interview together, in a social encounter that transcends the mere transfer of information. The validity and reliability of the information produced at this meeting depend on the establishment of a careful commitment between them, considering the epistemological and ethical aspects associated with the use of qualitative research (Paiva, Leão, \& Mello, 2011).

For the researcher, this commitment means, among other relevant items, those indicated in Table 1.

Table 1. Relevant factors for the researcher resulting from intersubjectivity.

\begin{tabular}{|c|c|}
\hline Relevant factor & Description \\
\hline \multirow{5}{*}{ Proper structuring } & $\begin{array}{l}\text { Know the subject discussed in the interview well enough to conduct the conversation properly and with } \\
\text { qualified guidance. }\end{array}$ \\
\hline & Develop methodologically congruent instruments to address the topic in focus. \\
\hline & Properly use the terminology related to the topic addressed, to be well understood by the participants. \\
\hline & Allow participants to understand the stages at which the interview will take place. \\
\hline & Enable participants to respond in their own way and time. \\
\hline \multirow{6}{*}{ Appropriate development } & $\begin{array}{l}\text { Be empathetic and sensitive to understand what is expressed by the participants, either verbally or non- } \\
\text { verbally. }\end{array}$ \\
\hline & Be aware of some interview aspects that may be more meaningful or sensitive to the participants. \\
\hline & Keep the focus on the topic addressed, bringing the conversation back to it whenever necessary. \\
\hline & $\begin{array}{l}\text { Check the reliability, validity, and consistency of the information produced during the conversation, } \\
\text { through questions or strategic interlocutions. }\end{array}$ \\
\hline & $\begin{array}{l}\text { Be able to recap the participants' previous statements about the topic addressed or pertinent to the } \\
\text { conversation. }\end{array}$ \\
\hline & $\begin{array}{l}\text { Clarify, with the participants, the senses and meanings they mention during the conversation, taking care } \\
\text { not to induce the answers. }\end{array}$ \\
\hline $\begin{array}{l}\text { Adequate analysis of the information } \\
\text { produced }\end{array}$ & $\begin{array}{l}\text { Be aware that the information produced is the result of an intersubjective social interaction, remaining } \\
\text { faithful to the senses and meanings attributed by the participants to their manifestations. }\end{array}$ \\
\hline
\end{tabular}

Note. Source: Author's own elaboration, from Kvale (1996).

Underlining intersubjectivity, Kitwood (1977) states:

However hard the researcher may try to be systematic and objective, by deciding on this form of research he has committed himself to a series of interactions which are subject to many of the constraints of everyday life. The solution is to have as explicit a theory as possible to take the various factors into account. For those who hold this view, there are not good interviews and bad in the conventional sense. There are simply social encounters; goodness and badness are predicates applicable, rather, to the theories within which the phenomena are explained (Kitwood, 1977, pp. 168-169).
The uniqueness of social encounters connects the interview to a direct relationship, in which the interchange is not restricted to the exchange of information. On the contrary, it extends to interactions in which the interviewer and interviewee mutually interfere in their points of view. The interview is a conversation in which the questions, far from being neutral, are presented in the cultural repertoires of all participants, indicating how people understand their social world and that of others (Kerlinger, 2007).

The interchange provided by the qualitative approach interview opens for the researcher a wide range of possibilities to investigate the horizons of the investigated, seeking to understand their points of view as subjects who experience 
the world in different ways. In Cannell and Kahn's (1968) definition, the interview appears as a "conversation initiated by the interviewer for the specific purpose of obtaining research-relevant information, and focused by him on content specified by research objectives" (Cannell \& Kahn, 1968 , p. 527). The interaction between the themes is direct, through verbal and non-verbal language.

Widely used in the field of social sciences since the 1980s, the interviews meet the need to employ alternative research methods to the positivist quantification of surveys, which reify the subjects, as well as the rough manipulation of behaviorist experiments. Qualitative interviews contrast with the alienated relationships between the research subjects, insofar as the conversation, through which they develop, suggests mutuality and egalitarianism. However, the fact that the relationship between the interviewer and the interviewee is direct and intersubjective does not prevent it from being asymmetrical or harboring the potential to manipulate the results (Kvale, 1996).

Often, the qualitative interview has been described inappropriately as dialogue. According to Kvale (2006), it is stated that interviews "give voice to the many. For example, the marginalized, who do not ordinarily participate in public debates, can in interview studies have their social situations and their viewpoints communicated to a larger audience" (Kvale, 2006, p. 481). It is a meeting, a conversation, an intersubjective and direct exchange. However, the interview and the dialogue differ substantially, in that the latter implies "a joint endeavor where egalitarian partners, through conversation, search for true understanding and knowledge" (Kvale, 2006, p. 483).

In this sense, the distinction between dialogue and interview is relevant, especially when the field of work is qualitative research in management, since the scientificity criteria inherent to academic research demand respect for clear methodological procedures, previously defined and aligned with an established objective. In general, it can be said that what brings the two terms together is the exchange between two or more people.

Buber (2001) emphasizes that in the exchange in the context of human life, 'I-Thou' and 'I-it' are the basic words that give meaning, respectively, to the relationship and to the experience. The interaction refers to a 'between,' an encounter in which whoever pronounces ' $I$ ' is related to 'Thou' or is linked to 'it.' The dialogue takes place in the 'between' of the 'I-Thou' relationship, in an authentic, direct, immediate encounter, in which the other is recognized and accepted in its total uniqueness.

The dialogic, for Buber, is a form of inter-human behavior, an opening 'between' people who are necessarily turned to each other. The author identifies three ways of perceiving the dialogue: (a) the authentic, "where each of the participants has in fact the other or the others in mind in their presence and in their way of being and turns to them with the intention to establish a living reciprocity between them and themselves"; (b) the technician, "driven only by the need for an objective understanding"; and (c) "the monologue disguised as dialogue," in which each person speaks only to himself (Buber, 1982, p. 53-54).

Dialogue differs precisely because it recognizes the other that transcends intersubjectivity. "More than an objective understanding of something, intimate knowledge would be someone's 'transjective' understanding" (Von Zuben, 2003, p. 11). This transjective understanding, required by authentic dialogue, is at the heart of the difference with the interview, in which, objectively, one of the subjects (interviewer) seeks understanding and the other (interviewee) provides subsidies for such understanding. Thinking of the interview as an authentic dialogue gives the illusion that the interviewer and the interviewee have converging interests, when, at least initially, the conversation of both takes place in the interest of the interviewer.

In this light, the interview is a unidirectional conversation, or, as Buber (1982) classifies, an instrumental dialogue. To admit this one-sidedness is not to defend the hierarchy of the encounter between interviewer and interviewee. However, it is essential to show that the interchange between subjects, in the interview, involves an asymmetric relationship, with an unequal distribution of power, in which the interviewer reserves the monopoly of interpretation for himself. The conversation is unidirectional also due to its flow: the interviewer asks and the interviewee answers. If the interviewer subverts this flow, the interview will no longer be useful for the research purposes. Under the researcher's control, an interview can be a form of manipulation, deliberate or not. Thus, the researcher must not lose sight of the fact that, if it is possible to understand the dialogue established with the interviewee as a conversation, an exchange that involves question and answer, it is not enough to consider only if the exchange is taking place, but also the relationships involved (power, asymmetry, symmetry).

Gaskell (2003) points out that the interview starts from an experiential world perspective: an unnatural social construction, made by people in their daily lives, but not under conditions that they themselves have established. Thus, the qualitative interview "provides the basic data for the development of an understanding of the relations between social actors and their situation" (Gaskell, 2003, p. 39). In addition to making an important distinction between individual and group interviews, the author also emphasizes the importance of preparing the researcher for the interview. According to him, it is necessary to know 
the theoretical and conceptual references of the interview, to have beforehand a guiding topic (which is not rigid) without forgetting to use the social imagination and, finally, to mount the selection of the interviewees in order to explore the spectrum of opinions and representations.

To a greater or lesser extent, the conversation is structured, satisfying the need for planning inherent in the research design - and this, in itself, already distances the interview from authentic dialogue, free from domination and between equal partners. The research project and the objective interest of the interviewer define the agenda and govern the conversation: the interviewer must have scientific competence to plan, define the time, choose themes and approaches, question, analyze responses, and disseminate results.

The researcher's commitment, as previously mentioned in Table 1, supports the use of qualitative interviews in research in administration according to ethical parameters, which must be observed in all stages, as suggested in the next segment of this paper.

\section{PRACTICAL STRUCTURING OF QUALITATIVE INTERVIEW IN ADMINISTRATION RESEARCH}

Based on the theoretical considerations raised in the previous segment, we reflected on the practical circumstances related to the use of qualitative interviews in administration research. To contribute to the researchers' work in this field, a simplified guide for the steps involved in using the interview was elaborated, highlighting its potentials and vulnerabilities.

However, please note that the guide is a set of suggestions and not a universal model. It is intended to draw attention to some important topics to be considered, without, therefore, offering a standardized model for the use of this method, which is impossible or, at least, of little use for research in administration.

\section{Why use the qualitative interview in administration research?}

For the researcher, an interview is a conversation with the intention of achieving different purposes, systematized in Figure 2.

The purposes of using the interview derive from the research objectives, formulated within a theoretical framework ${ }^{1}$. The methodology, which includes the methods and, among them, the interview, places the phenomena and circumstances of the empirical universe in interface with the theoretical framework, as shown in Figure 3.

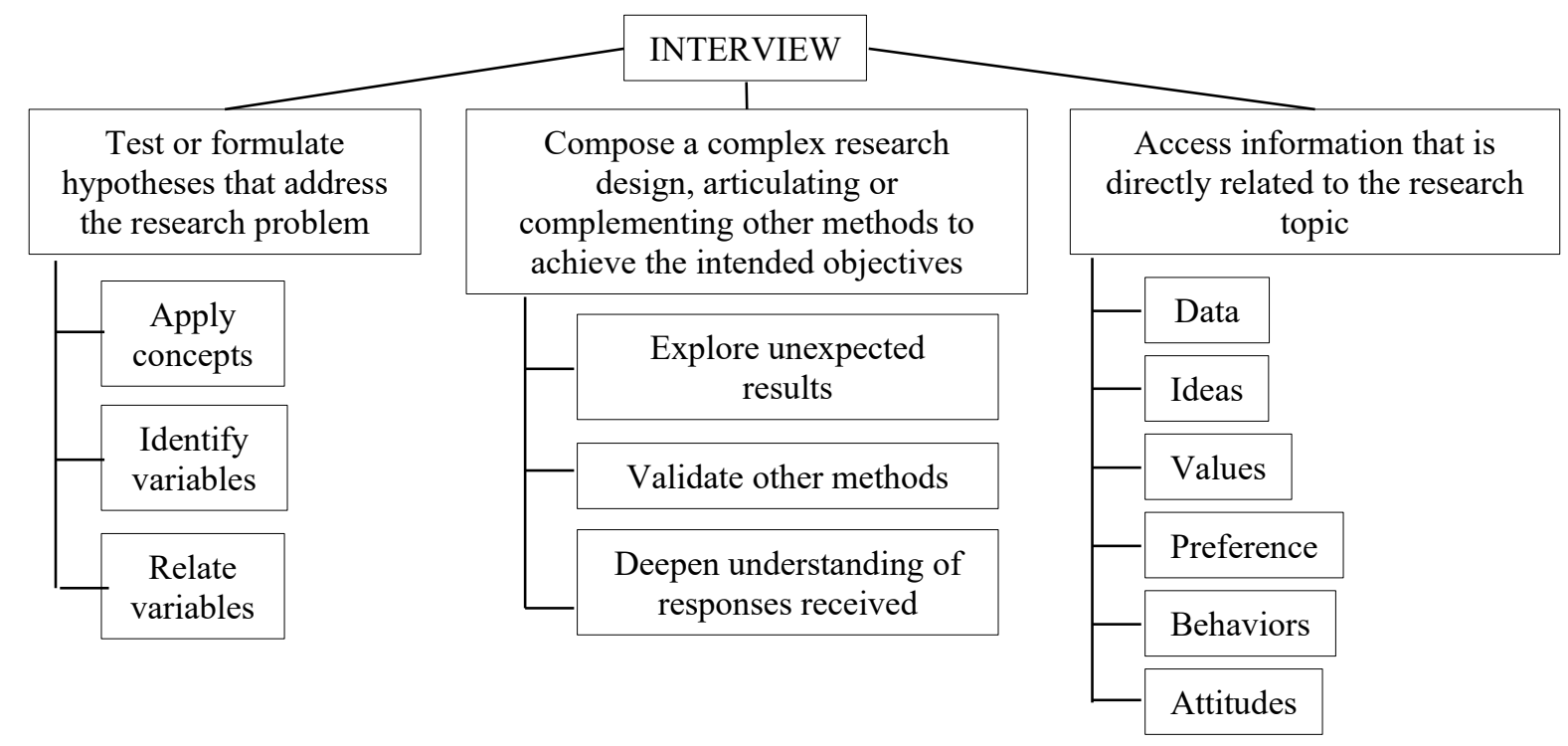

Figure 2. Purposes of using the interview in administration, according to the researcher's perspective.

Source: Author's own elaboration. 


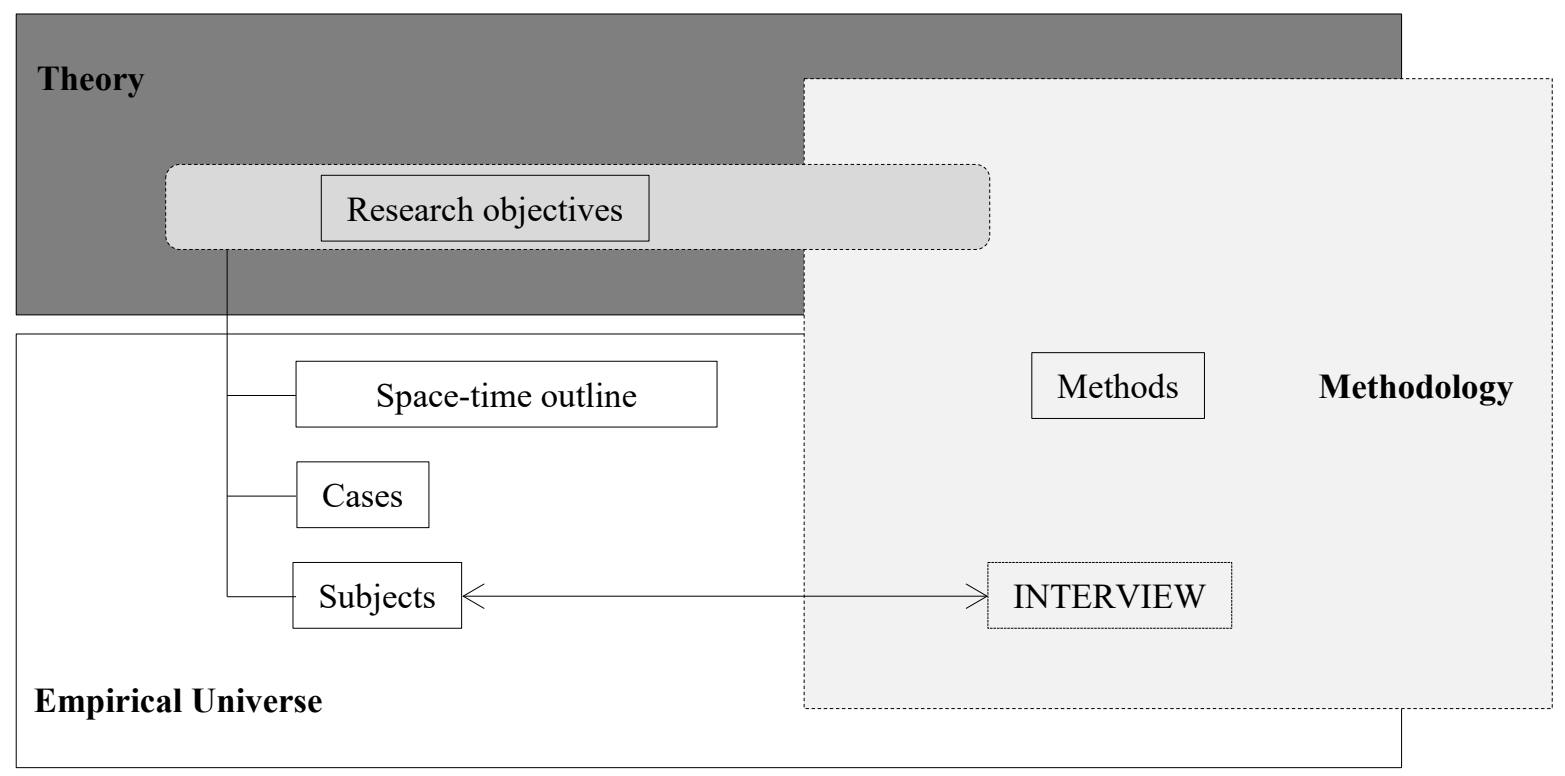

Figure 3. Relationship between theory, empirical universe, and methodology, placing the interview according to the research objectives.

Source: Author's own elaboration, from Sautu, Boniolo, Dalle, and Elbert (2005).

The research objectives derive from a given theoretical perspective and constitute the link between theory and methodology. Thus, the objectives are fundamental for the research, and it must necessarily be possible to be achieved by the methods chosen by the researcher. This leads to considering, when choosing the interview, the potential that this method has to achieve the intended purposes, as well as the inherent vulnerabilities.

\section{What are the kinds of qualitative interviews most commonly used in administration research?}

In administration, as in other areas of knowledge, the interview can serve the researcher in several ways, in close connection with the disciplinary context, the themes worked on, the theoretical framework, and the empirical universe. Table 2 emphasizes some of the possible situations in which the interview is strategically useful for research in administration.

According to Patton (1980), there are different types of interviews in qualitative or mixed research approaches that can bring advantages and disadvantages for the researcher, as summarized in Table 3.

The differentiation between the types of interviews, in practice, lies in the greater or lesser degree of structuring of the questions, which reflects the purposes for which it is intended and, therefore, the research objectives. It is important to note that less structuring does not mean less planning of the interview: all types require researcher preparation, organization, and programming. The choice for one or another type of interview will necessarily be based on the adoption of a consistent theoretical framework that supports the construction of the problem and the research objectives, from which the subjects involved are defined, which, in turn, requires some knowledge of the empirical universe.

In addition, it is worth mentioning two other modalities, although less usual. The first is the narrative interview, which comprises the act of telling a story: "a context is given; events are sequential and end at a certain point; the narration includes a type of the result evaluation" (Jovchelovitch \& Bauer, 2003, p. 92). The second is the so-called episodic interview, created to delimit certain conceptions in concrete terms, in which the interviewee is encouraged to narrate events, situations, or episodes in a concrete way, starting from what he considers relevant (Flick, 2003). With a more objective character, the technique seeks to "analyze the interviewee's daily knowledge on a specific topic or field, in such a way that it allows comparing the respondents' knowledge from different social groups" (Flick, 2003. p. 118). 
Table 2. Possible situations in which the interview is strategically useful for research in administration.

\begin{tabular}{ll}
\hline Research subjects & What does the researcher seek with the use of the interview? (Examples of possibilities) \\
\hline Aspects of human and social behavior & $\begin{array}{l}\text { Understanding knowledge, values, beliefs, or decision-making processes of stakeholders. } \\
\text { Explore the contextual experience, actions, and relationships within the interview process, instead of just } \\
\text { describing behaviors or classifying the subjects. } \\
\text { Understand the scenario of the relationships between the components and members of specific organizations or } \\
\text { groups from the point of view of the interviewee. } \\
\text { Understand specific interactions that involve more than one group. }\end{array}$ \\
$\begin{array}{l}\text { Understand a trajectory, an event, a specific or emblematic process for the research problem. } \\
\text { Devecific cases, singular or in a }\end{array}$ & $\begin{array}{l}\text { Understand the perceptions of specific individuals. } \\
\text { Comparative perspective }\end{array}$ \\
$\begin{array}{l}\text { Reflect on the conditions in which the educational context can be transformed or reformed. } \\
\text { Check the congruence of a given theory in a changing scenario. } \\
\text { Suggest solutions for problems in the administrative field. } \\
\text { Check changes or transformations in a given organizational context, based on actions or interventions. }\end{array}$ \\
\hline
\end{tabular}

Note. Source: Author's own elaboration.

Table 3. Types of interviews according to the questions structure, possibilities of use, requirements for the researcher, potential advantages and disadvantages.

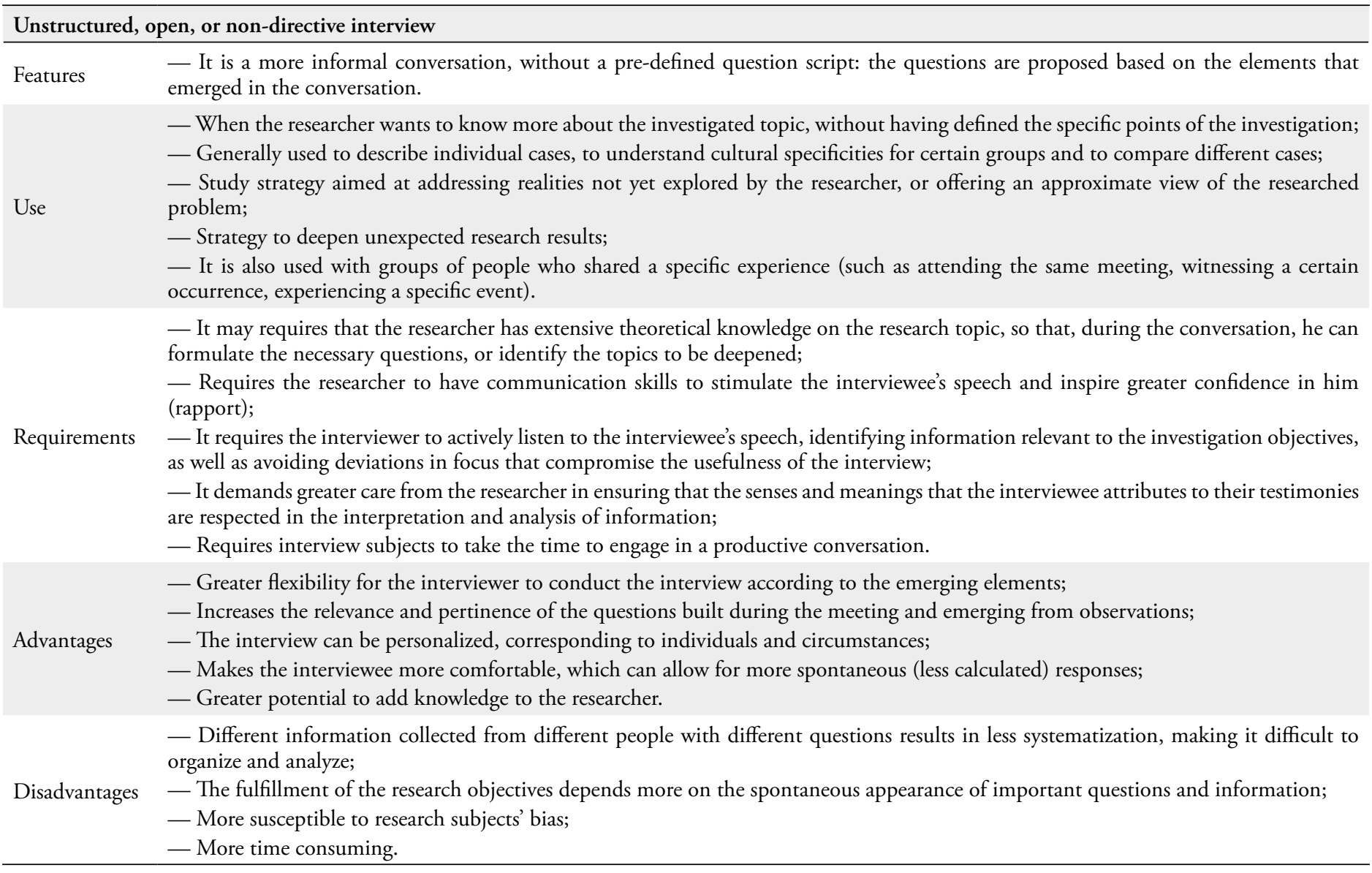


Table 3. Types of interviews according to the questions structure, possibilities of use, requirements for the researcher, potential advantages and disadvantages (Continued).

\section{Semi-structured, semi-open, or semi-directive interview}

- The topics and questions to be addressed are specified in advance, in the form of a script with central questions, based on theories and hypotheses ${ }^{2}$ related to the research problem, complemented by other questions inherent to the momentary circumstances of the

Features interview;

- The researcher combines open and closed questions and decides their sequence and convenience during the interview: questions can be modified, included, or deleted.

- When the researcher wishes to delimit the volume of information produced in the interview, thus obtaining a greater focus on the topic, intervening to guarantee the achievement of the research objectives;

Use - When the researcher intends to maximize the understanding about the description of a certain social phenomenon, and asks questions from a phenomenological theoretical framework;

- When the researcher intends to establish causalities or explanations for social phenomena, and elaborates questions from a historicalstructural (dialectical) theoretical framework.

— In addition to the requirements mentioned for the open interview, the interviewer must be attentive to direct, at the time he deems

Requirements appropriate, the discussion to the relevant topics previously defined, or to bring the conversation back to the proposed focus;

- Relative knowledge of the theoretical and empirical universe addressed.

- It allows, at the same time, the interviewee freedom of expression and the maintenance of the focus by the interviewer;

- It allows access to the unobservable, causing the interviewee to reflect, and access to current representations, even of past events;

- Enables unobservable elements to be identified and related to other elements relevant to the research;

Advantages - It allows evaluating the coherence or incoherence of the information obtained, performing procedures that increase its validity and reliability, such as the triangulation of sources $^{3}$, for example;

- Allows greater systematization of the information produced in relation to the unstructured interview, facilitating its interpretation and analysis;

— Allows possible gaps to be anticipated and solved.

— Topics relevant to an investigation may be inadvertently omitted;

Disadvantages — The interviewer's flexibility to conduct the questioning can result in substantially different responses, thereby reducing their comparability.

Structured, closed, or directive interview ${ }^{4}$

Features $\quad-$ The exact wording and the sequence of questions are determined in advance;

- All respondents receive the same basic questions in the same order.

- When the researcher seeks to know the interviewee's points of view and circumstances in a comparative perspective, based on specific

Use $\quad$ information, previously defined;

- When the researcher wants to interview a larger number of people, whose perspectives and situations will be categorized and compared.

- Prior knowledge of the empirical universe, in order to ensure that the topics and questions include the elements necessary to achieve

Requirements the research objectives;

— Clear and understandable wording of the questions for all respondents.

- It allows responses to be different due to the elements investigated, the interviewee's perspectives and circumstances, and not because they answer different questions;

Advantages - Increases the comparability of responses in relation to the semi-structured interview;

- Enables the involvement of a larger number of respondents in the investigation;

- Reduces the potential for a posteriori bias in the information built by pre-defining the topics and categories covered by the questions;

- Allows the researcher to delegate the interviews conduct to other interviewers simultaneously, reducing the time taken.

- Increases the potential for skewed information produced by inducing respondents from the topics and categories covered by the Disadvantages questions;

— Less flexibility, not allowing exploring unexpected responses from respondents that raise potentially relevant topics for investigation.

Note. Source: Author's own elaboration.

The conduct of the focus group and the

It is suggested that, based on Kvale (1996), the interview planning be carried out following seven steps, illustrated in Figure 4.
The first step consists in choosing the theme and elaborating the problem and research objectives, guided by a consistent theoretical framework. The definition of the interview as a methodological strategy is based on this theoretical framework, which guides the researcher to pay 
attention to factors that concern both the method and the research objectives. In this sense, the researcher has limited choices due to the ability to achieve the objectives outlined (usefulness of the interview as a method), objective limitations (financial resources, time, access to interviewees), ethical issues (confidentiality and use of information, for example), and institutional demands (administrative procedures, institutional policies).
The research design is the subsequent step, in which the concepts indicated by the theoretical framework are operationalized and the information that will answer the research problem is listed and categorized. Here, the researcher chooses the type of interview (see Table 3) that best fits the factors mentioned above, with more or less structuring of topics and questions.

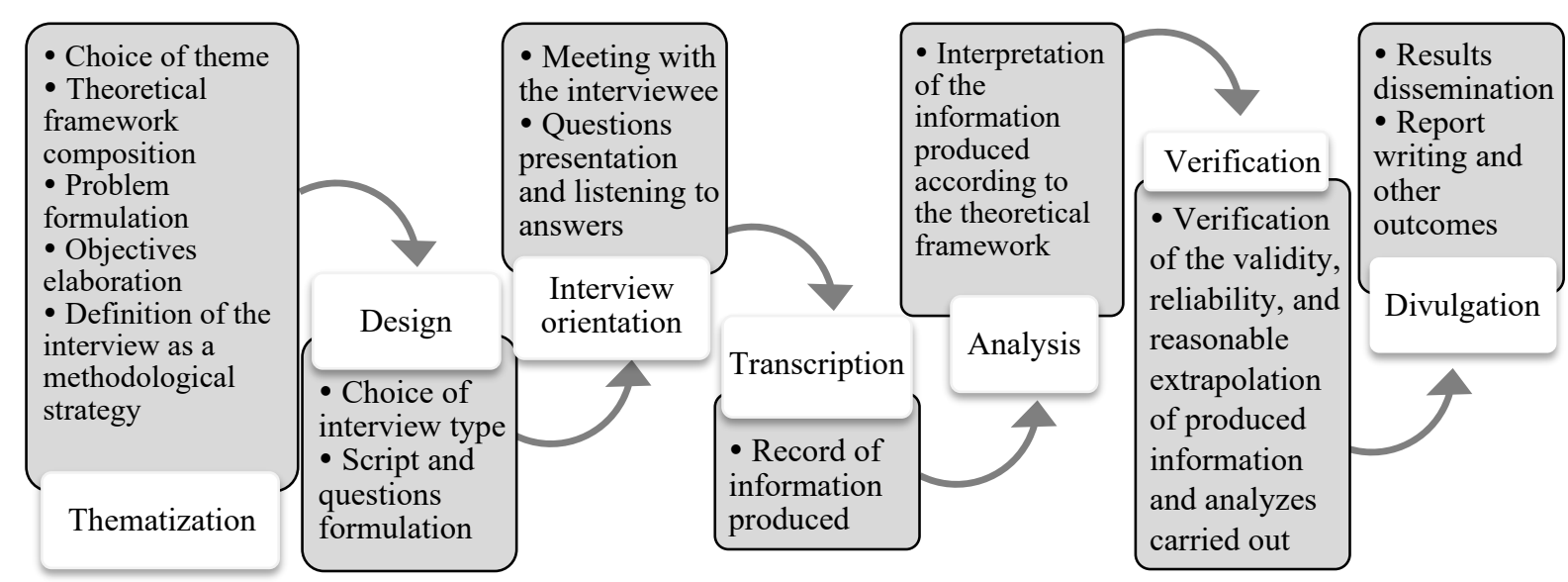

Figure 3. Planning steps for a research in administration, considering the qualitative interview as a methodological strategy. Source: Author's own elaboration, from Kvale (1996).

\section{What question formats are used in a qualitative interview in administration research?}

Depending on the degree of structuring proposed for an interview, the researcher will ask different questions covering: (a) the topics of a script for a semi-structured interview; and (b) the questions and answers for the semistructured and structured interviews.

The script consists of a list of topics that the interviewer intends to address during the interview. For its elaboration, the researcher needs a reasonable knowledge of the theory and the empirical universe of the study, in order to select themes relevant to the achievement of the research objectives. If he does not know the theoretical framework of the study well enough, he may subsequently face great difficulties in the interpretation, analysis, and construction of sufficient results to answer the research problem. If, on the other hand, he ignores the empirical universe under investigation, he will find it difficult to define essential aspects of the method, such as who to interview, when, where, and how. In the latter case, a recommended strategy is to conduct an exploratory study to learn about the object, planning a research design integrated by mixed or articulated methodological approaches 5 .
According to Patton (1980), some elements are key to the elaboration of a semi-structured interview script, among which: (a) definition of the topics to be discussed, based on the concepts indicated by the theoretical framework; (b) possible questions that can be related to each topic; (c) possible obstacles to addressing each topic (for example, sensitive issues or communication difficulties), and strategies for solving them; and (d) stimuli related to each topic (data, narratives, images, hypothetical situations, among others).

The questions of a qualitative interview can be asked according to multiple criteria, as shown in Table 4.

Just as the questions have different formats, by varying criteria, the answers provided by the interviewee may also vary, according to the researcher's definitions.

The questions and answers, as Triviños (2009) warns, should not be ties that hinder the research, but instruments that open possibilities of work for the researcher. Because of this, the combination of different question formats in the same interview can increase its viability to achieve the research objectives. Qualitative questions are usually developed or refined at all stages of a reflective and interactive research journey. Flick (2009) notes that "reflecting on and reformulating the research questions are central points of reference for assessing the appropriateness of the decisions you take at several points" of research (Flick, 2009, p. 105). 
Table 4. Different question formats, by definition, classification, and examples.

\begin{tabular}{|c|c|c|c|}
\hline Criterion & Format & Features & Examples (based on supposed leadership research) \\
\hline \multirow{2}{*}{$\begin{array}{l}\text { Regarding the } \\
\text { format of the } \\
\text { interviewee's } \\
\text { responses }\end{array}$} & $\begin{array}{l}\text { Questions with the } \\
\text { possibility of open answers }\end{array}$ & $\begin{array}{l}\text { The interviewee formulates the answers in his } \\
\text { own way, within the subject proposed by the } \\
\text { interviewer }\end{array}$ & — In your opinion, what is leadership? \\
\hline & $\begin{array}{l}\text { Questions with the } \\
\text { possibility of closed answers }\end{array}$ & $\begin{array}{l}\text { The interviewee chooses his answer among the } \\
\text { alternatives presented by the interviewer }\end{array}$ & $\begin{array}{l}\text { _ Do you consider leader and boss to be synonymous? } \\
\text { (a) yes } \\
\text { (b) no } \\
\text { (c) I don't know }\end{array}$ \\
\hline
\end{tabular}

$\begin{aligned} & \text { Questions that address the } \\ & \text { Regarding the } \\ & \text { approach to } \\ & \text { the research } \\ & \text { topic }\end{aligned}$
$\begin{aligned} & \text { Questions that address the question deals with the subject investigated } \\ & \text { topic indirectly }\end{aligned}$

Sociodemographic information

Experience and behavior

Experice and

Emotion

Regarding the questions content
Knowledge or description

(in

Sensory information

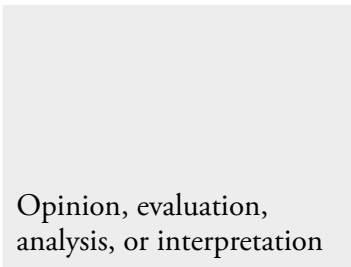

Opinion, evaluation,
analysis, or interpretation
The question asks the interviewee to provide characteristics about himself, in order to help the researcher situate him in relation to the other people in a group or society

The question asks the respondent to report his experience, or to show his behavior or attitude toward a certain element, which can be presented through encouragement

The question seeks to understand the interviewee emotional responses to his experiences and reflections; when targeting feelings, these questions differ from those related to the interviewee's opinions

The question asks the respondent to state what they know about a specific element; it is different from the questions about the interviewee's opinion

The question is focused on what the interviewee perceives with the senses of sight, hearing, touch, smell, and taste

Questions designed to understand the cognitive and interpretive processes of the interviewees; the question asks the interviewee to express what he thinks, his goals, intentions, desires, and values; these questions usually involve an implication in the interviewee's rationality
- What are the main skills of a leader in your organization?

- How do you perceive the relationship between the organizational climate and the need for employee representation in senior management positions in a company?

— What is your age?

- What gender do you identify with?

- What is your marital status?

- What is your reaction when you did not identify in one of your company leaders the necessary conditions to be in management position?

- If you were invited to a leadership position, but you didn't feel prepared, what would you do?

— How do you feel when you interact with your leader?

- You mentioned a successful initiative in the leadership training program, adopted by another company. What is the name of this company?

- What is the recommended procedure for retaining talent in your company?

- You said that you heard a striking phrase from a colleague who later came to occupy a leadership position. What was the phrase?

- To what do you attribute the occurrence of turnover among leaders in your company?

- In your opinion, how effective are the policies and practices of training, development, and education of existing leaders in organizations?

- What do you mean by leadership?

- What is your level of agreement with the following statement: "The teams that stand out the most are those with more humanitarian leaders"?
(a) disagrees
(b) does not disagree or agree
(c) agree

Note. Source: Author's own elaboration, from Patton (1980), Spradley (1979), and Triviños (2009).

\section{How to conduct a qualitative interview in administration research?}

Once the types of interviews and question formats are defined, the next step is to meet with the interviewee. At this point, some aspects about the choice of the interviewees earn to be highlighted. This process is broader than just sample selection techniques, including challenges such as accessing participants, justifying and reporting your choice. The researcher must be concerned with choosing people who in almost all cases will be asked if they consent to participate. Although occasionally, it may be possible to choose 
potential participants from a target population, instead of a sample. How many participants will be sufficient for the research to be considered authentic and reliable? When discussing this, the researcher should consider the research planning empirically based and question the adequacy of the data saturation pattern. Another challenge is to ensure transparency in the selection criteria, conducting the process in an ethical manner and ensuring respect for the rights of participants.

Table 5 points out some recommendations to the interviewer at this stage.

Table 5. Recommendations to the interviewer when conducting the interview.

\begin{tabular}{|c|c|}
\hline Recommendation & Description \\
\hline Transparency & $\begin{array}{l}\text { - Communicate in a very clear and positive way the objective, the probable duration, the nature and content of the interview, } \\
\text { taking care not to influence the responses; } \\
\text { - Explain the process of conducting the interview; } \\
\text { - Explain how the responses will be recorded (notes, audio, video) and how the information will be used, ensuring that the } \\
\text { interviewee gives his free and informed consent for this; } \\
\text { - During the interview, the interviewer's bias and values should not be revealed; } \\
\text { If necessary, guide the interviewees on topics or questions, or refocus the interview. }\end{array}$ \\
\hline Rapport & $\begin{array}{l}\text { - Establish the conversation in an empathetic and professional manner; } \\
\text { - Give the interviewee the opportunity to ask questions; } \\
\text { — Be sensitive to the interviewee's emotions, avoiding judgments, showing signs of annoyance or impatience; } \\
\text { — Ensure that the interviewee is comfortable and willing to talk; } \\
\text { — Take into account the interpersonal, interactional, communicative, and emotional aspects of the interview; } \\
\text { — Actively listen to the interviewee. }\end{array}$ \\
\hline Conversation flow & $\begin{array}{l}\text { - Concern about how to maintain the conversation, stimulating the interviewee's speeches in a careful and conscious way about } \\
\text { the possible problems resulting from the asymmetry in the established relationship; } \\
\text { - Use, as necessary or convenient, progressively directive strategies: } \\
\text { — Make encouragement sounds; } \\
\text { - Referring to the interviewee's statements; } \\
\text { - Explore the interviewee's positions; } \\
\text { - Introduce new topics; } \\
\text { - Distribute the questions in order to facilitate the interviewee's answers: } \\
\text { More 'descriptive and immediate' questions should be asked before 'how?' or 'why?', more elaborate and reflective; } \\
\text { Non-controversial topics should be addressed before more controversial topics. }\end{array}$ \\
\hline Difficulties forecast & $\begin{array}{l}\text { - Avoid external interruptions (third party intervention, phone calls, etc.); } \\
\text { - Minimize distractions (TV on, side conversations, etc.); } \\
\text { - Ensure that the interview is convenient at the moment (appropriate place, schedule, and time); } \\
\text { - Prevent the interviewee's or interviewer's inhibition from making conversation impossible; } \\
\text { - Avoid using terms that the interviewee is not familiar with; } \\
\text { - If the interview is carried out remotely, or involves self-applied instruments (via online form, email, phone, or other means), } \\
\text { ensure that the questions are sufficiently clear and will be well understood by the interviewee; } \\
\text { - If the researcher delegates the interview to interviewers, ensure that they receive the necessary information and training; } \\
\text { — Ensure that the interviewee can be contacted in the future for clarification or validation of the interview; } \\
\text { - Predict and resolve possible reasons that the interviewee may have for not participating in the interview or not answering a } \\
\text { certain question. }\end{array}$ \\
\hline
\end{tabular}

Note. Source: Author's own elaboration, from Kvale (1996).

It is also important that the interviewer presents himself adequately to the interviewee, providing elements that identify him and the institution, company, or agency to which he is linked, so that the interviewee can perform, if desired, a security check. On the other hand, the validation of information demands that the interviewee can be properly identified and located by the researcher, without compromising the ethical duty of confidentiality, when required.
The application of appropriate ethical principles is important in any research study. In a qualitative study, ethical considerations have a particular resonance due to the profound nature of the study process. Concern about ethical issues becomes more prominent when conducting a face-to-face interview with participants who may be potentially harmed by the exposure of certain data, or because they are approached in a careless manner, for example. While ethical considerations are important in all research areas, the concern becomes more 
salient in qualitative research. It is the responsibility of the researcher to ensure participants have the power of freedom of choice to be involved in the study, to protect the participants' identity throughout recruitment and dissemination process, and to promote clear and honest research reporting.

\section{What are the main factors to consider when transcribing, analyzing, and disseminating research results?}

It should be noted that, specifically, the analysis of the information constructed from the interviews goes beyond the scope of this article. However, it is recommended that the researcher keeps in mind that his research objective, his theoretical-analytical framework, and the information constructed have a close correlation with the methods and techniques he will use. In addition to this care, although the interview is described as a social, intersubjective, and interactive encounter, it is necessary for the researcher to record the information produced, not only to form the research corpus, but also for its documentation, respecting the criteria of scientific knowledge ${ }^{6}$. In this stage, some important points are highlighted in Table 6.

It is important to note that the construction of the corpus must reach a degree of saturation, which occurs when the "inclusion of a new extract does not represent anything new. It is assumed that the representational variety is limited in time and social space" (Bauer \& Aarts, 2003, p. 59).

It is necessary to point out, however, that the epistemic position adopted rejects the notion that interviews are merely a technique or data collection strategy. When we refer to intersubjectivity and the factors arising from it, we are linking to the perspective defended by Kvale (1996; 2006), Kitwood (1977), Gunzenhauser (2013), Unger (2005), and other authors who have worked with the qualitative approach in a critical way. Data are not merely collected, but produced by interviewer and interviewee, who interact. Thus, the analysis of information begins with the researcher still in the field, favored by using flexible instruments (Guilherme \& Cheron, 2021). Table 7 shows the analysis strategies most frequently associated with the use of qualitative interviews.

Table 6. Possible difficulties that the researcher will face in transcribing, interpreting, analyzing, and disseminating the research results, and care to deal with them.

\begin{tabular}{ll}
\hline \multicolumn{1}{c}{ Possible difficulties } & \multicolumn{1}{c}{ Care that the researcher must take } \\
\hline Loss of information & $\begin{array}{l}\text { Record the information properly; } \\
\text { Know how to distinguish which information is relevant to the research objectives, and which is not. }\end{array}$ \\
& $\begin{array}{l}\text { Admitting that all forms of information transcription, analysis, and dissemination imply some degree of distortion, to be added } \\
\text { to the bias already mentioned; } \\
\text { Pay attention to the senses and meanings attributed by the interviewees to their own statements; } \\
\text { Pay attention to the consistency between the concepts operationalized in the interview, the information produced, and the } \\
\text { researcher's considerations when interpreting, analyzing, and disseminating the results; }\end{array}$ \\
Avoid generalizing the search results beyond the reasonable extrapolation allowed by the information produced.
\end{tabular}

Note. Source: Author's own elaboration.

Table 7. Qualitative analysis strategies most frequently associated with the use of qualitative interviews.

\begin{tabular}{|c|c|}
\hline Analysis strategy & Description \\
\hline Narrative research & $\begin{array}{l}\text { Study of the subjects' lives, from which the researcher requests narratives about their individual trajectories, which are } \\
\text { recounted or re-established by the researcher in the chronology. }\end{array}$ \\
\hline Thematic analysis & Grouping of data by theme and evaluation of all cases. \\
\hline Grounded theory & Inductive process of identifying analytical categories as they 'emerge' from the data. \\
\hline Coding cycles & Cyclic, non-linear analytical process, in steps: (a) data coding; (b) construction and/or articulation of categories. \\
\hline $\begin{array}{l}\text { Interpretive phenomenological } \\
\text { analysis }\end{array}$ & Analysis that seeks to understand how people experience and describe their world, and how they build meanings. \\
\hline Framework & Deductive form that aims to connect qualitative and quantitative approaches. Evolution of matrix-based methods. \\
\hline Content analysis & Systematic analysis of texts, through a system of categories developed from the material and guided by theory. \\
\hline
\end{tabular}

Note. Source: Author's own elaboration, from Guilherme and Cheron (2021). 
The research can result in several products: report, book, scientific article, documentary, toolbox, website, game, or app, among many others. Communications of research results, in whole or in part, are often written texts, according to scientific criteria and formatting standards, which present the researcher's work to the public.

The questions (outline of topics or questions) and the transcript of the interviews, if they have been prepared by the researcher, can appear in the Appendices. However, if the researcher used questions elaborated or interviews transcribed by another author, they are part of the Annexes of the research communication.

\section{CONCLUSION}

The intention of this article was to provide researchers in administration and related topics with a horizon about the qualitative approach interview, its characteristics, advantages, disadvantages, and the main practical circumstances involved in its use. In conclusion, some last points are highlighted that, it is suggested, the researcher observes when dealing with interviews: the asymmetry of the relationship with the interviewee, the inevitable presence of biases and distortions, and the rigor in the research planning.

As seen, the interview constitutes a direct relationship between the interviewer and the interviewee, both subjects of the research. This relationship, however, differs from the open dialogue between equal partners. Instead, the interview is an objective, instrumental, and, to a greater or lesser extent, hierarchical conversation, in which the interviewer defines the scenario and plot according to his interests, within the scope of the investigation. Neglecting this asymmetry does not mean reducing biases or distortions, but, on the contrary, amplifies them, and can seriously impair the validity of the knowledge built.

Distortions and biases are ubiquitous and inescapable in any research; it would not be different with those in which the researcher uses interviews. In this specific context, the biases arise from the different ways of seeing, being, feeling, understanding, and representing the world, both from the interviewer/researcher and from the interviewee, as well as from circumstantial factors that are beyond the scope of these subjects. The bias starts, if not before, when the researcher chooses the research topic, composes the theoretical framework, selects relevant concepts, and operationalizes them in questions to be proposed to the interviewee. The biases persist during the conduct of the interview itself, advance through the transcription, interpretation, and analysis of information produced, and are prolonged in the dissemination of results.

To claim the research authorship, planning it rigorously, is not to adopt a rigid stance, but to commit oneself to the investigation. It is up to the researcher to constitute a theoretical reference consistent with the theme and intended objectives, understanding it well enough so that he can identify and operationalize the concepts with coherence. Equally, it is the researcher's job to know the object of the study, in the empirical universe, enough to articulate a research design that is congruent and useful to its objectives, enabling the construction of knowledge that qualifies and values the interviewee's active participation.

\section{NOTES}

1. About the hypothesis formulation and development, see Gilgun (1992).

2. According to Gilgun (1992), the qualitative approach interview has great potential in the process of generating hypotheses from empirical, qualitative data. The author argues that a discovery-oriented qualitative method of hypothesis generation has great capacity for the development of social knowledge. The conceptual framework, the research question, the sample, and the hypotheses evolve in response to the empirical patterns that the researcher discovers in the conduct of the research.

3. For knowledge about the validity and reliability of the research, cf. Paiva, Leão, and Mello (2011).

4. Although structured interviews are more related to quantitative studies, they are referred to here in comparison to other formats, as a way of differentiation and also because of the mentioned potential for using combined approaches.

5. To learn more about research designs and mixed or articulated approaches, we suggest reading the specific chapter of Creswell's (2012, p. 534-575) work.

6. On the criteria of scientific knowledge, see Kerlinger (2007, p. 1-21). 


\section{REFERENCES}

Bauer, M., \& Aarts, B. (2003). A construção do corpus: Um princípio para a coleta de dados qualitativos. In $\mathrm{M}$. W. Bauer \& G. Gaskell (Eds.), Pesquisa qualitativa com texto, imagem e som: Um manual prático. Petrópolis, RJ: Editora Vozes.

Becker, H. S. (1993). Métodos de pesquisa em ciências sociais. São Paulo: Editora Hucitec.

Buber, M. (1982). Do diálogo e do dialógico. São Paulo: Editora Perspectiva.

Buber, M. (2001). Eu e tu (8 ed.). São Paulo: Editora Centauro.

Cannell, C. F., \& Kahn, R. L. (1968). Interviewing. In G. Lindzey, E. Aronson (Eds.), The handbook of social psychology (Vol. 2, pp. 526-595). New York: Addison-Wesley.

Creswell, J. W. (2012). Qualitative inquiry and research design: Choosing among five approaches. Thousand Oaks, CA: Sage.

Flick, U. (2003). Entrevista episódica. In M. W. Bauer \& G. Gaskell (Eds.), Pesquisa qualitativa com texto, imagem e som: Um manual prático. Petrópolis, RJ: Editora Vozes.

Flick, U. (2009). An introduction to qualitative research (4 ed.). London: SAGE Publications.

Gaskell, G. (2003). Entrevistas individuais e grupais. In M. W. Bauer \& G. Gaskell (Eds.), Pesquisa qualitativa com texto, imagem e som: Um manual prático. Petrópolis, RJ: Editora Vozes.

Gilgun, J. F. (1992). Hypothesis generation in social work research. Journal of Social Service Research, 15(3-4), 113-135. https://doi.org/10.1300/J079v15n03 07

Guilherme, A. A., \& Cheron, C. (2021). Guia prático de pesquisa em Educação. Caxias do Sul, RS: EDUCS.

Gunzenhauser, M. G. (2013). From empathy to creative intersubjectivity in qualitative research. Counterpoints, (354), 57-74. Retrieved from http://www.jstor.org/stable/42981163

Jovchelovitch, S., \& Bauer, M. (2003). Entrevista narrativa. In M. W. Bauer \& G. Gaskell (Eds.), Pesquisa qualitativa com texto, imagem e som: Um manual prático. Petrópolis, RJ: Editora Vozes.

Kerlinger, F. N. (2007). Metodologia da pesquisa em Ciências Sociais: Um tratamento conceitual. São Paulo: Editora Pedagógica e Universitária.
Kitwood, T. M. (1977) Values in adolescent life: Towards a critical description (Doctoral dissertation). University of Bradford, School of Education, Bradford, England. Retrieved from https://ethos.bl.uk/OrderDetails.do?uin=uk. bl.ethos. 462205

Kvale, S. (2006). Dominance through interviews and dialogues. Qualitative Inquiry, 12(3), 480-500. https://doi.org/10.1177/1077800406286235

Kvale, S. (1996) InterViews: An introduction to qualitative research interviewing. London: SAGE Publications.

Lanka, E., Lanka, S., Rostron, A., \& Singh, P. (2021). Why we need qualitative research in management studies. Revista de Administração Contemporânea, 25(2), e200297. https://doi.org/10.1590/1982-7849rac2021200297.en

Paiva, F.G., Júnior, Leão,A. L.M.S., \&Mello,S.C. B. (2011).Validade e confiabilidade na pesquisa qualitativa em administração. Revista de Ciências da Administração, 13(31), 190-209. https://doi.org/10.5007/2175-8077.2011v13n31p190

Patton, M. Q. (1980). Qualitative evaluation methods. London: SAGE Publications.

Rodrigues, L. P., Neves, F. M., \& Anjos, J. C. (2016). A contribuição da Sociologia à compreensão de uma epistemologia complexa da ciência contemporânea. Sociologias, 18(41), 24-53. https://doi.org/10.1590/15174522-018004102

Santos, B. S. (1987). Law: A map of misreading. Toward a postmodern conception of law. Journal of Law and Society, 14(3), 279-302. https://doi.org/10.2307/1410186

Sautu, R., Boniolo, P., Dalle, P., \& Elbert, R. (2005). Manual de metodologia: Construcción del marco teórico, formulación de los objetivos y elección de la metodologia. Buenos Aires: CLACSO.

Spradley, J. P. (1979). The ethnographic interview. New York: Holt, Rinehart and Winston.

Triviños, A. N. S. (2009). Introdução à pesquisa em Ciências Sociais: A pesquisa qualitativa em Educação - o positivismo, a fenomenologia, o marxismo (5 ed.). São Paulo: Atlas.

Unger, M. P. (2005). Intersubjectivity, hermeneutics, and the production of knowledge in qualitative mennonite scholarship. International Journal of Qualitative Methods, 4(3), 50-62. https://doi. org/10.1177/160940690500400304

Von Zuben, N. A. (2003). Martin Buber: Cumplicidade e diálogo. Bauru: EDUSC. 


\section{Authorship}

\section{Cibele Cheron}

Pontifícia Universidade Católica do Rio Grande do Sul, Escola de Humanidades, Programa de Pós-Graduação em Educação

Av. Ipiranga, n. 6681, Jardim Botânico, 90610-001, Porto Alegre, RS, Brazil

E-mail: iccibele@gmail.com

(D) https://orcid.org/0000-0003-3501-5248

\section{Julice Salvagni*}

Universidade Federal do Rio Grande do Sul, Escola de Administração

Rua Washington Luiz, n. 855, Centro Histórico, 90010-460, Porto Alegre, RS, Brazil

E-mail: julicesalvagni@gmail.com

(D) https://orcid.org/0000-0002-6334-0649

\section{Renato Koch Colomby}

Instituto Federal de Educação Ciência e Tecnologia do Paraná, Colegiado de Administração

Av. Bento Munhoz da Rocha Neto, s/no, PRT-280, Trevo da Codapar, 85555-000, Palmas, PR, Brazil

E-mail: renato.colomby@gmail.com

(D) https://orcid.org/0000-0002-5013-6913

* Corresponding Author

\section{Conflict of Interests}

The authors have stated that there is no conflict of interest.

\section{Funding}

The authors reported that there is no financial support for the research in this article.

\section{Authors' Contributions}

$1^{\text {st }}$ author: conceptualization (equal); investigation (equal); methodology (equal); writing - original draft (lead); writing review $\&$ editing (equal).

$2^{\text {nd }}$ author: conceptualization (equal); investigation (equal); methodology (equal); writing - original draft (supporting); writing - review \& editing (equal).

$3^{\text {rd }}$ author: conceptualization (equal); formal analysis (supporting); methodology (supporting); supervision (supporting); writing - review \& editing (equal).

\section{Copyrights}

RAC owns the copyright to this content.

\section{Plagiarism Check}

The RAC maintains the practice of submitting all documents approved for publication to the plagiarism check, using specific tools, e.g.: iThenticate.

\section{Peer Review Method}

This content was evaluated using the double-blind peer review process. The disclosure of the reviewers' information on the first page, as well as the Peer Review Report, is made only after concluding the evaluation process, and with the voluntary consent of the respective reviewers and authors.

\section{Data Availability}

RAC encourages data sharing but, in compliance with ethical principles, it does not demand the disclosure of any means of identifying research subjects, preserving the privacy of research subjects. The practice of open data is to enable the reproducibility of results, and to ensure the unrestricted transparency of the results of the published research, without requiring the identity of research subjects. 